\title{
Cerebrospinal Fluid Findings in Six Dogs with Neurological Disease
}

\author{
Cecilia-Gabriella DANCIU ${ }^{1 *}$, Ciprian Andrei OBER ${ }^{2}$, Cosmin PEȘTEAN ${ }^{3}$, Marian TAULESCU ${ }^{4}$, Cristina \\ ȘTEFĂNUT, ${ }^{1}$, Octavia TAMAS-KRUMPE ${ }^{1}$, Liviu OANA ${ }^{2}$ and Laurenț OGNEAN ${ }^{1}$ \\ ${ }^{1}$ Department of Physiology, University of Agricultural Science and Veterinary Medicine Cluj-Napoca, Romania \\ ${ }^{2}$ Department of Surgery, University of Agricultural Science and Veterinary Medicine Cluj-Napoca, Romania \\ ${ }^{3}$ Department of Anesthesiology and Intensive Care, University of Agricultural Science and Veterinary Medicine \\ Cluj-Napoca, Romania \\ ${ }^{4}$ Department of Pathology, University of Agricultural Science and Veterinary Medicine Cluj-Napoca, Romania \\ *corresponding author: cecilia_danciu@yahoo.com
}

Bulletin UASVM Veterinary Medicine 76(1)/2019

Print ISSN 1843-5270; Electronic ISSN 1843-5378

doi:10.15835/buasvmcn-vm: 2018.0051

\begin{abstract}
The aim of the study was to emphasize the cerebrospinal fluid (CSF) findings in dogs with neurological pathology and to support the clinical relevance of the CSF analysis in patients with neurological diseases. A total of six dogs with pleocytosis, from different breeds were included in this study. Cisternal tap was processed and CSF workup was done in all six. Elevated cell count, increased protein level and cytological findings like lymphocytic, monocytic and mixed pleocytosis were also observed. CSF cytological findings were consistent with inflammatory disorders. CSF analysis is a safe diagnostic tool for detecting central nervous system inflammation in our study, still not confirmatory based solely for definitive diagnosis.
\end{abstract}

Keywords: cerebrospinal fluid, cytology, dogs, neurology

\section{Introduction}

Diagnosis of central nervous system (CNS) pathology in dogs can be challenging, because of the few tests that supply information about the CNS integrity ante-mortem (Bohn et al., 2006).

Cerebrospinal fluid (CSF) analysis is recommended if a multifocal CNS or meningeal involvement of the disease is suspected based on the neurological examination and neuroanatomical localization (Bush et al., 2002; Podell, 1996).

CSF analysis is an ancillary test, which has been used for diagnostic evaluation of suspected CNS disease. Abnormalities can be recognized in CSF with inflammatory, infectious, neoplastic, traumatic, vascular and degenerative disorders of the CNS (Abate et al., 1998; Jamison and Lumsden, 1988). Moreover, analysis of the CSF was shown to be the most valuable diagnostic test for inflammatory conditions in the central nervous system. Additional CSF protein and white cell increase can be found in $90 \%$ of the affected dogs (Tipold, 1995).

The purpose of this study wasto retrospectively evaluate the cerebrospinal fluid findings in six neurologically affected dogs and to describe the findings.

According to our knowledge this is the first study which establishes cerebrospinal fluid findings in dogs in Romania.

\section{Materials and methods}

This study was conducted at teaching Hospital of the Faculty of Veterinary Medicine Cluj-Napoca, Romania between October 2017 to May 2018. The selection of cases was based on the presence of pleocytosis in CSF analysis and the availability of full clinical information (including: signalment, neurological examination, 
complete blood count and biochemistry, CSF cytology, computed tomography scan, and urinalysis). The characteristics of CSF cell count, cytology and CSF protein level abnormality were recorded and described. Exclusion criteria included the presence of paraparesis/paraplegia on neurological examination, intervertebral disc herniation and neuromuscular diseases, and presence of iatrogenic blood contamination of the CSF. Pleocytosis was described if there were >5 nucleated cells/mL (Chrisman, 1992; Bagley and Bohn, 2003; Bush et al., 2002). Protein concentration was considered elevated if $>25 \mathrm{mg} /$ dL (Bagley and Bohn, 2003).

CSF cisternal tap (Platt, and Olby, 2013) was performed under general anesthesia. Preanesthesia and induction of anesthesia was personalized based on age, clinical and paraclinical status. Maintenance of anesthesia for CT scan and CSF cisternal tap was performed with isoflurane in $100 \%$ oxygen.

The CSF was collected in sterile tubes without any additive (Platt and Olby, 2013). Prior to the tap, CT images were analyzed to exclude any cerebellar herniation through Foramen Magnum and the patients were clipped and the collection of CSF was performed under sterile conditions (Platt and Olby, 2013).

Cerebrospinal fluid investigation included: gross physical examination, protein determination using urine dipsticks (CybowUrine Reagent Strip, DFI, Korea) or UV-VIS spectrophotometery (Screen Master Touch, Hospitex Diagnostics, Italy), total erythrocyte and leucocyte count in a standard hemocytometer (Neubauer Improved, Hirschmann, US) and cerebrospinal fluid cytological evaluation. For cytological evaluation samples were concentrated using a Shandon 4 Cytospin (Thermo Scientific, UK), volumes of 100 $\mathrm{ml}$ of CSF being centrifuged at 800 speed rotation/ minute for 10 minutes at room temperature (Platt and Olby, 2013). Smears were stained with DiffQuik (Reagens, Hungary) and further examined using an Olympus BX51 lightmicroscope (Olympus, Tokyo, Japan). The bright field images of the cytology samples were obtained by an Olympus SP 350 digital camera and further processed using Olympus Cell B software. CSF cytology samples were revised by a board certified pathologist (MT).

Computed tomography (16 slice Siemens Somatom Scope, Siemens, UK) images were re- viewed by the authors using medical image viewer (Horos Dicom viewer, version 2.1.1, www. horosproject.org). CT findings were not the objective of this study and are found elsewhere (Plummer et al., 1992; Talarico and Schatzberg, 2010).

Diagnosis based only on the CSF findings was not confirmatory, unless other confirmatory tests (e.g. serum titers) were performed.

\section{Results}

Of the fourteen dogs, six dogs met the criteria for inclusion in the study, represented by three Mixed Breeds, one French Bulldog, one Dogo Argentino and one Romanian Mioritic Shepherd Dog. Median age of the dogs was three years and seven months (1.5 - 7 years). Three dogs were female and three dogs were male. Female dogs were all spayed and the male dogs were distributed to one intact and two castrated.

Median duration of the clinical signs prior the presentation at the hospital was seven days (extending from 1 to 15 days). The most frequent argument for presentation involved the following neurological signs: mentation changes in four dogs, circling in one dog, progressive tetraparesis was noted in three dogs, head tilt was observed in one dog and cervical pain. Onset of clinical signs was acute in five dogs and chronic in one dog. Signalments and clinical signs are shown in Table 1.

Clinical signs related to disease in other organs was recorded in two dogs of six. Of these two dogs, one dog had gastrointestinal disease (vomiting and diarrhea) and the other dog had signs of infection of the eyes (purulent conjunctivitis) and nasal discharge.

Neurological examination revealed abnormalities in all dogs, of which four were described mildly obtunded. One dog presented with left sided conscious proprioception deficit, and three dogs had progressive tetraparesis. One dog presented at the neurological examination left sided head tilt, absent left sided menace response and absent left sided palpebral reflex. One dog beside the mildly obtundation was circling to the right side. The dog with other clinical signs than neurological ones, purulent conjunctivitis, presented also with absent right sided pupillary light reflex, absent right sided menace response. One dog presented with acute cervical pain. 
Diagnostic findings recorded on the patients were abnormal in three dogs. One dog had slight neutrophilia measuring $17.64 \times 10^{9} / \mathrm{L}$ (reference interval: $6.0 \times 10^{9}$ to $\left.17.0 \times 10^{9} / \mathrm{L}\right)$. One $\operatorname{dog}$ had moderate neutophilia measuring $24 \times 10^{9} / \mathrm{L}$ (reference interval: $6.0 \times 10^{9}$ to $17.0 \times 10^{9} / \mathrm{L}$ ). One

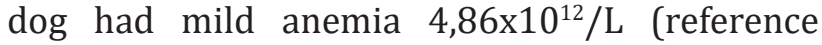
interval: $5.5 \times 10^{12}$ to $8.5 \times 10^{12} / \mathrm{L}$ ) and moderate

Table 1. Clinical and CSF findings in the six dogs

\begin{tabular}{|c|c|c|c|c|c|c|}
\hline Case & $\begin{array}{c}\text { Breed, } \\
\text { Gender, Age- } \\
\text { years }(y), k g\end{array}$ & Clinical presentation & $\begin{array}{c}\text { Neuroanato- } \\
\text { mical } \\
\text { localization }\end{array}$ & $\begin{array}{c}\text { CSF } \\
\text { cell } \\
\text { count }\end{array}$ & CSF Cytology & $\begin{array}{c}\text { CSF } \\
\text { Protein }\end{array}$ \\
\hline 1. & $\begin{array}{c}\text { Mixed Breed } \\
\text { Female } \\
\text { spayed } \\
6 \text { y, } 19\end{array}$ & $\begin{array}{c}\text { Bright, alert responsive, } \\
\text { Acute left sided head } \\
\text { tilt, Absent left menace, } \\
\text { Absent left palpebral, } \\
\text { Delayed left conscious } \\
\text { proprioception }\end{array}$ & $\begin{array}{c}\text { Focal } \\
\text { Brainstem }\end{array}$ & $\begin{array}{c}39 \\
\text { cells / } \\
\mathrm{mm}^{3}\end{array}$ & $\begin{array}{l}\text { Monocytic, } \\
\text { Lymphocytic } \\
\text { pleocytosis }\end{array}$ & $\begin{array}{r}>30 \mathrm{mg} / \\
\mathrm{dL}(1+)\end{array}$ \\
\hline
\end{tabular}

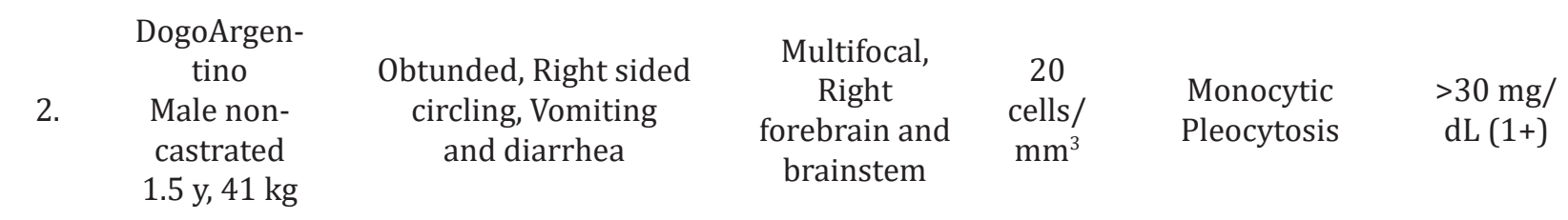

\begin{tabular}{|c|c|c|c|c|c|c|}
\hline 3. & $\begin{array}{l}\text { Romanian } \\
\text { Mioritic } \\
\text { Shepherd } \\
\text { Dog } \\
\text { Male cas- } \\
\text { trated } \\
2 \mathrm{y}\end{array}$ & $\begin{array}{c}\text { Obtunded, Progressive } \\
\text { non-ambulatory } \\
\text { tetraparesis }\end{array}$ & $\begin{array}{l}\text { Focal } \\
\text { brainstem }\end{array}$ & $\begin{array}{c}36 \\
\text { cells / } \\
\mathrm{mm}^{3}\end{array}$ & $\begin{array}{l}\text { Lymphocytic } \\
\text { pleocytosis }\end{array}$ & $\begin{array}{l}>30 \mathrm{mg} / \\
\mathrm{dL}(1+)\end{array}$ \\
\hline 4. & $\begin{array}{l}\text { Mixed Breed } \\
\text { Male non- } \\
\text { castrated } \\
2 y\end{array}$ & $\begin{array}{c}\text { Obtunded, Absent left } \\
\text { sided PLR, Absent } \\
\text { left menace, Acute } \\
\text { progressive non- } \\
\text { ambulatory tetraparesis, } \\
\text { Present reflexes, } \\
\text { Purulent conjunctivitis }\end{array}$ & $\begin{array}{l}\text { Multifocal, } \\
\text { Left forebrain } \\
\text { and brainstem }\end{array}$ & $\begin{array}{c}45 \\
\text { cells/ } \\
\mathrm{mm}^{3}\end{array}$ & $\begin{array}{c}\text { Mixed } \\
\text { Pleocytosis }\end{array}$ & $50 \mathrm{mg} / \mathrm{dL}$ \\
\hline 5. & $\begin{array}{l}\text { Mixed Breed } \\
\text { Female } \\
\text { spayed } \\
4 \mathrm{y}\end{array}$ & $\begin{array}{l}\text { Bright, Alert, Responsive, } \\
\text { Acute cervical pain }\end{array}$ & C1-C5 & $\begin{array}{l}135 \\
\text { cells/ } \\
\mathrm{mm}^{2}\end{array}$ & $\begin{array}{l}\text { Mixed pleocytosi, } \\
\text { predominantly } \\
\text { monocytes }\end{array}$ & $\begin{array}{l}>30 \mathrm{mg} / \\
\mathrm{dL}(2+)\end{array}$ \\
\hline 6. & $\begin{array}{l}\text { French } \\
\text { Bulldog } \\
\text { Female } \\
\text { spayed } \\
7 \mathrm{y}\end{array}$ & Obtunded, tetraparesis & $\begin{array}{l}\text { Multifocal, } \\
\text { forebrain and } \\
\text { brainstem }\end{array}$ & $\begin{array}{l}358 \\
\text { cells / } \\
\mathrm{mm}^{2}\end{array}$ & $\begin{array}{c}\text { Mixed } \\
\text { pleocytosis }\end{array}$ & $52 \mathrm{mg} / \mathrm{dL}$ \\
\hline
\end{tabular}

Note: $1+$ : $30 \mathrm{mg} / \mathrm{dL} ; 2+$ : $100 \mathrm{mg} / \mathrm{dL}$ (Platt and Olby, 2013) 


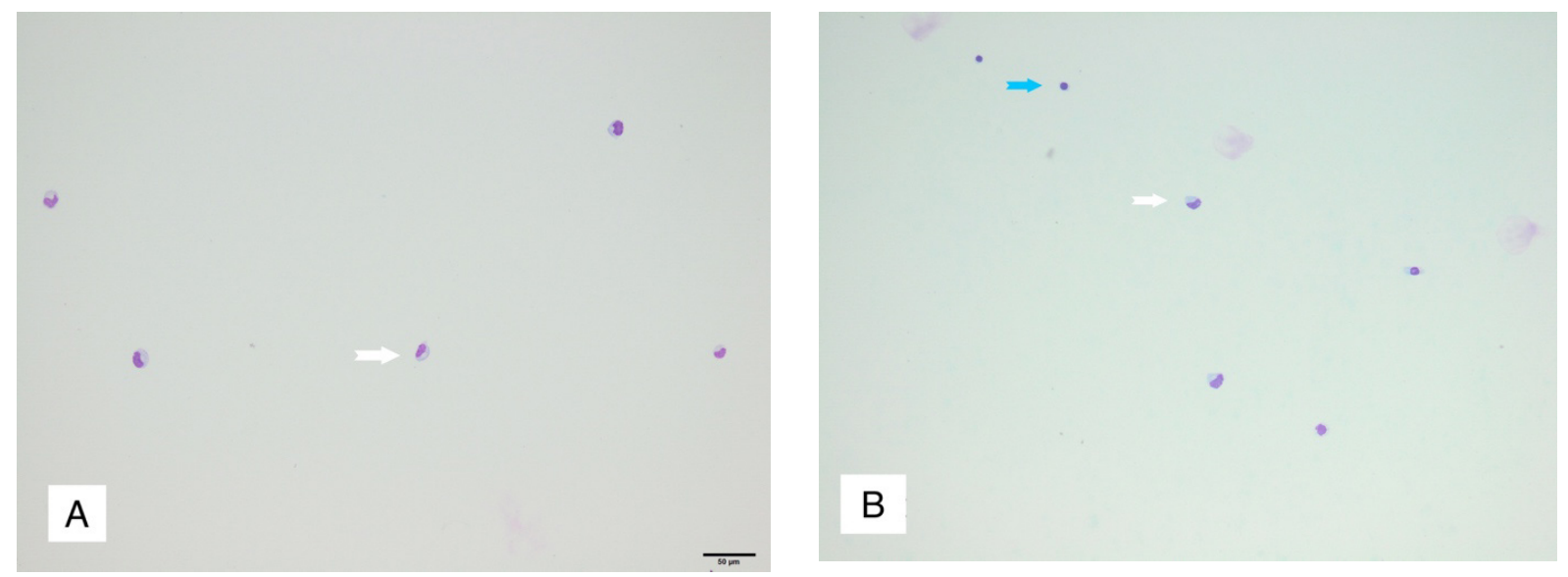

Figure 1. CSF cytology finding in the fourth case: A. Mild to moderate mixed pleocytosis, monocyte (white arrow), B. lymphocyte (blue arrow); Diff-Quik stain, obx50
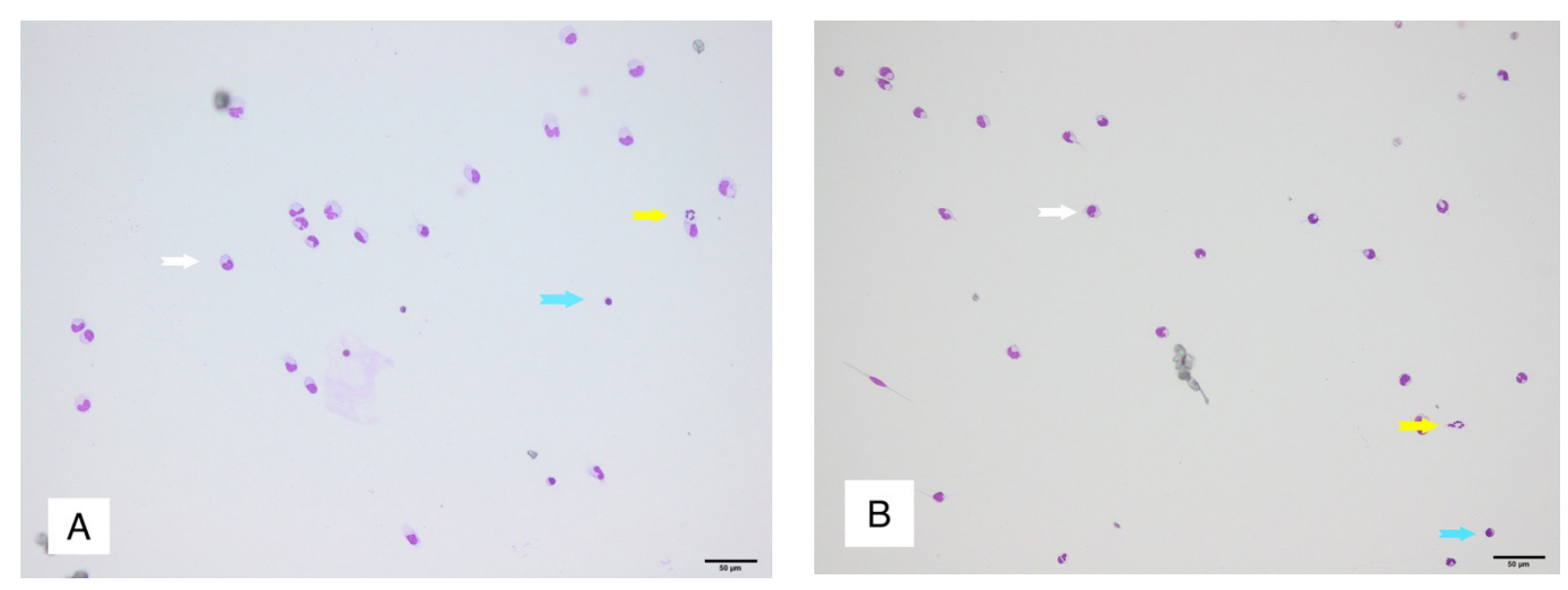

Figure 2. CSF cytological finding in the fifth case: A. and B. Mixed pleocytosis, predominantly monocyte (white arrow), lymphocyte (blue arrow) and neutrophil (yellow arrow); Diff-Quik stain, obx50
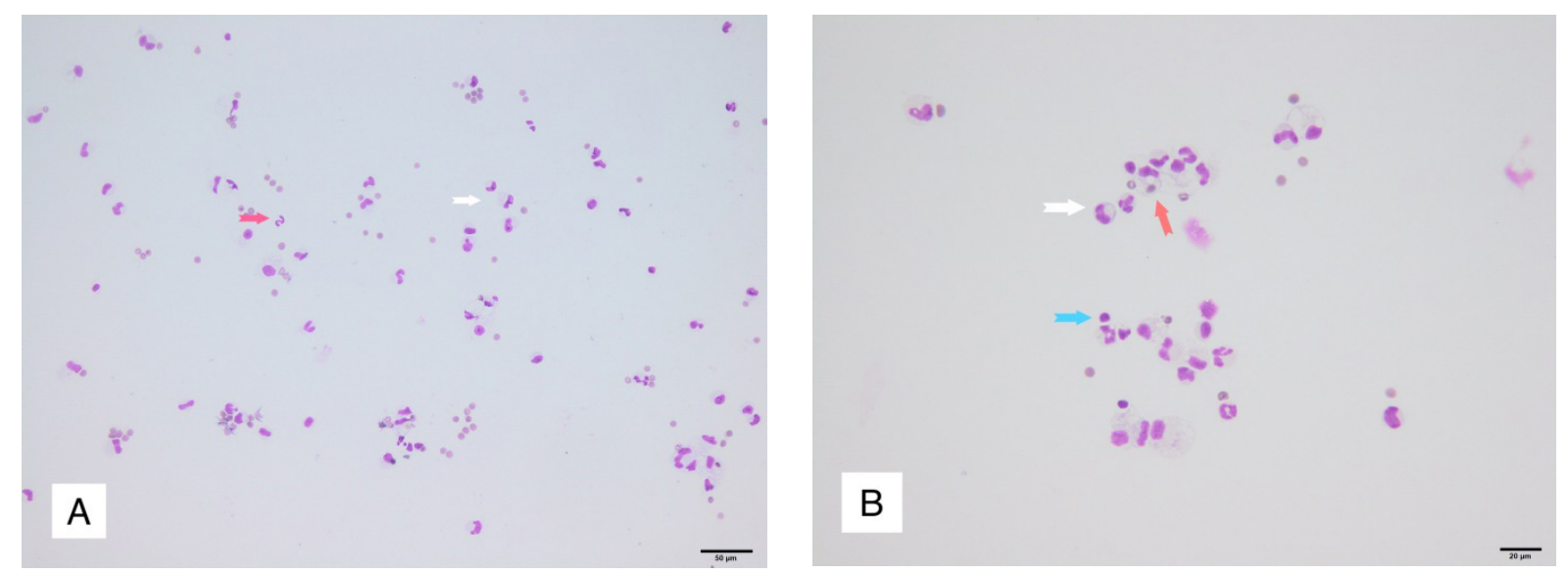

Figure 3. CSF cytological finding in the sixth case: A. Mixed pleocytosis with macrophages (white arrow) and neutrophil (red arrow); Diff-Quik stain, obx50; B. Mixed pleocytosis with erythrophagocytosis (red arrow), macrophages (white arrow) and lymphocyte (blue arrow); Diff-Quik stain, obx100 (oil imersion) 
lymphopenia $0.18 \times 10^{9} / \mathrm{L}$ (reference interval: $1 \times 10^{9} / \mathrm{L}$ to $4.8 \times 10^{9} / \mathrm{L}$ ). White blood cell count of the other three dogs were within normal limits. On the biochemistry profile one dog had changes on the creatin kinase, $399.9 \mathrm{U} / \mathrm{L}$, which exceeded the reference interval: 30 to $100 \mathrm{U} / \mathrm{L}$.

CSF analysis revealed abnormal cell count in all six dogs, pleocytosis was present in every case. Median total nucleated cell count was 105 cells/ $\mathrm{mm}^{3}$ (varying from 20 to 358 cells $/ \mathrm{mm}^{3}$ ). CSF total protein exceeded the reference values in all the dogs (reference interval: $<25 \mathrm{mg} / \mathrm{dl}$, result higher than $30 \mathrm{mg} / \mathrm{dl}$ interpreted as $1+$, higher than $100 \mathrm{mg} / \mathrm{dl}$ interpreted as 2+)(Platt, and Olby, 2013). Four dogs had CSF protein evaluated on urine dipstick from whom three had resulted 1+ $(30 \mathrm{mg} / \mathrm{dL})$ and one had $2+(100 \mathrm{mg} / \mathrm{dL})$. The rest of the dogs had CSF protein evaluated on spectrophotometery and appeared to be mildly elevated, $50 \mathrm{mg} / \mathrm{dL}$ and $52 \mathrm{mg} / \mathrm{dL}$.

CSF cytological abnormalities were found in all cases, predominantly mixed pleocytosis in three cases (Figure 1, Figure 2 and Figure 3), monocytic in two dogs (Figure 1. and Figure 2.) and lymphocytic in the last dog (Figure 3).

Computed tomography scans of the brain were reviewed, of all dogs and one scan of six was abnormal. Abnormality was defined as a hyperattenuating mass in the right lateral ventricle (Figure 7.).
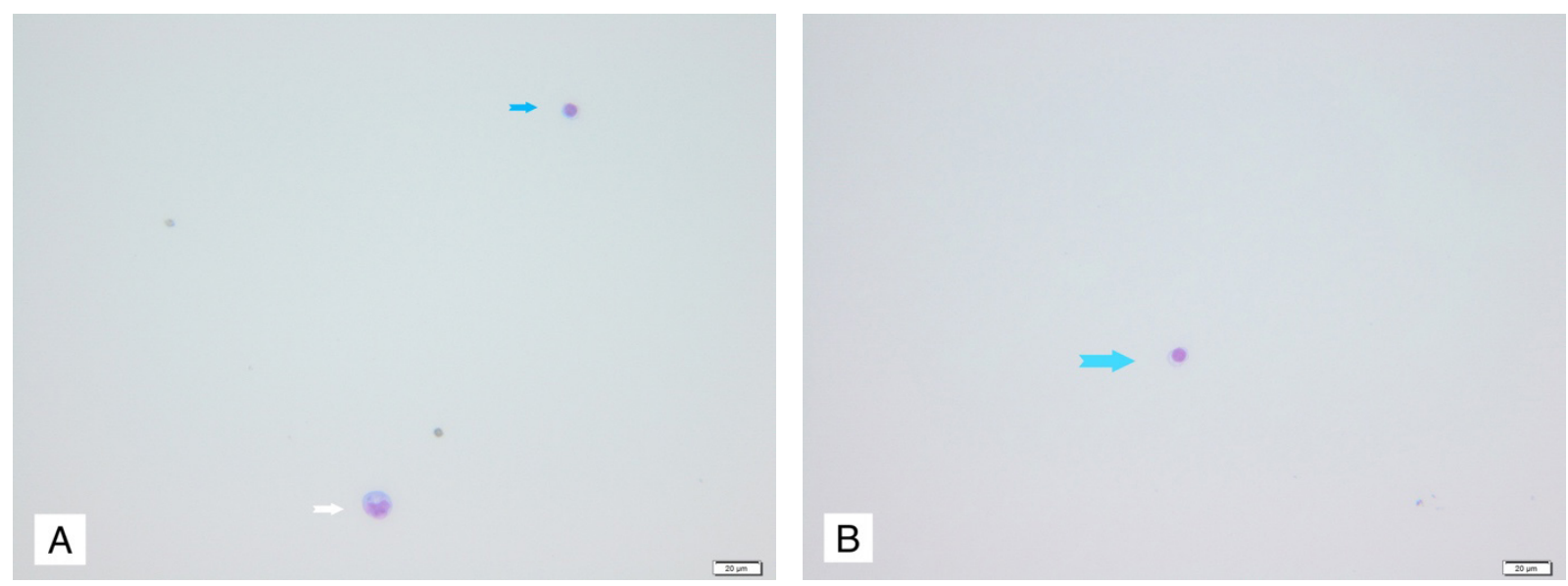

Figure 4. CSF Cytology finding in case 1: A. mild monocytic pleocytosis, lymphocyte (B.) (bluearrow) and monocyte (white arrow); Diff-Quik stain, obx100 (oil imersion)

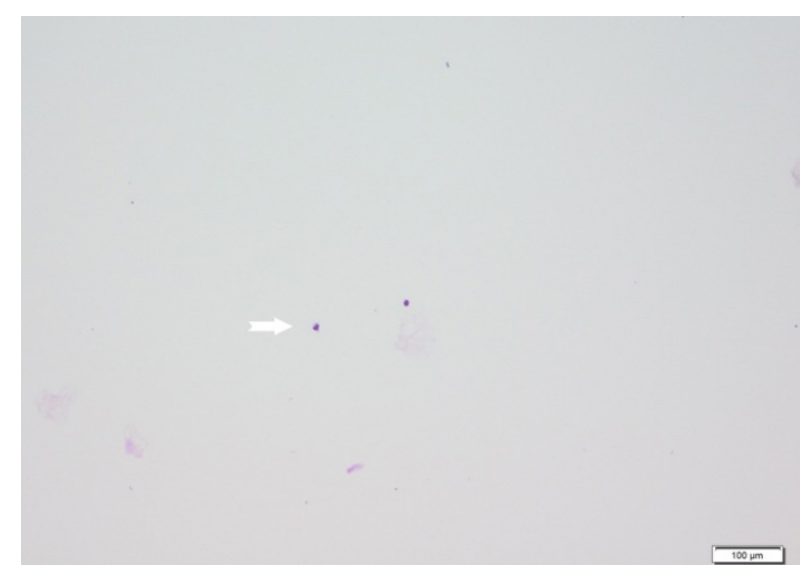

Figure 5. CSF cytology finding in case 2: Monocytic pleocytosis (white arrow); Diff-Quik stain, obx100 (oil imersion)

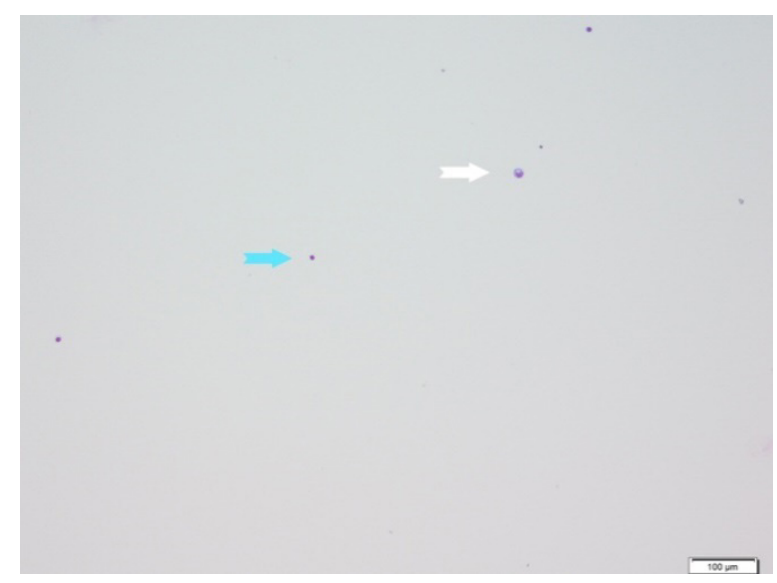

Figure 6. CSF cytology finding in case 3: Predominantly lymphocytic pleocytosis (white arrow) with monocytes (blue arrow); Diff-Quik stain, obx100 (oil imersion) 


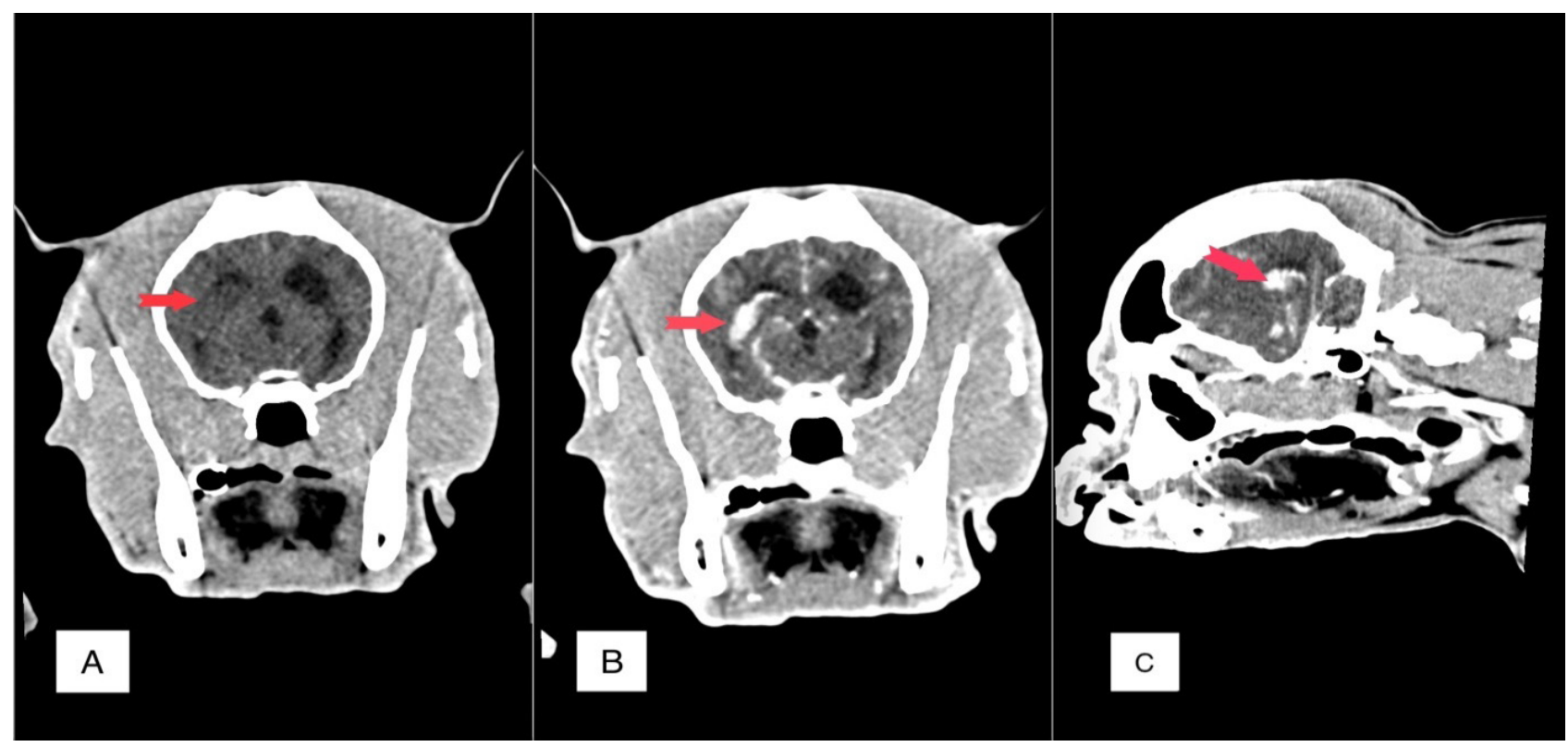

Figure 7. Computed tomography, brain window images: Case 6, A. Axial image of the head, with a space occupying lesion (red arrow) in the right lateral ventricle, B. Axial post contrast image of the head with a hyperattenuating mass (red arrow) in the right lateral ventricle, C. Sagittal Post contrast image of the head, with a hyperattenuating mass (red arrow) in the right lateral ventricle

Postmortem examination was available in one of the cases, due to the fact that three dogs are still alive, two dogs had incomplete follow-up and one dog was euthanized to the owner request.

\section{Discussions}

This study evaluated the cerebrospinal fluid findings in six dogs with neurological abnormalities. Our findings may be useful and sustain the importance of CSF evaluation in focal and multifocal forebrain signs in dogs. Lesions were affecting mostly the forebrain and brainstem, resulting in abnormal mentation, cranial nerve deficits or tetraparesis. Focal forebrain clinical signs, usually consisting of seizures, mental status change, circling, and central visual impairment (Braund, 1985) were identified in three of our cases (case 2, 4 and 6) and, can be the result of a single, space-occupying lesion, a localized ischemic or inflammatory process (Adamo et al., 2007). Focal brainstem signs, present in two of our cases (case 1, 3, 4 and 6) can result in hemiparesis to tetraplegia, multiple cranial nerve deficits and central vestibular syndrome (Braund, 1985). Cervical pain was present in one dog (case 5), reflecting the meningeal involvement (Da Costa, 2012).
Dogs had a median cell count of 105 cells/ $\mathrm{mm}^{3}$ (varying from 20 to 358 cells $/ \mathrm{mm}^{3}$ ). The most common cytological abnormality in our study was mixed pleocytosis (monocytic and lymphocytic) identified in 3 cases. In addition to mixed monocytic and lymphocytic pleocytosis, 2 cases included in our study showed monocytic pleocytosis and one lymphocytic pleocytosis. Monocytic and lymphocytic pleocytosis can be associated with granulomatous meningoencephalitis (GME) and with canine distemper virus (CDV) infections (Greene and Appel, 1990; Chrisman, 1992; O'Neill et al., 2005). In order to reach the diagnosis of CDV, serology or polymerase chain reaction testing can help to demonstrate the infectious agent (Schatzerg et al., 2005; Barber et al., 2012). CDV infection was confirmed by serological testing in one case (case 4). In case number 6, the cause of mixed pleocytosis was associated with choroid plexus papilloma (confirmed by histopathology). For the other 4 cases the etiology of lymphocytic pleocytosis was not confirmed.

Our results were consistent with other studies, in which they showed that CSF analysis is the most helpful detecting CSF inflammatory diseases (Bohn et al., 2006; Tipold, 1995). Moreover, we have to consider, that other studies showed pleocytosis 
not only by primary CNS inflammation, but also in inflammation in response to trauma, neoplasia, infarcts or hemorrhage (Bagley and Bohn, 2003; Lamb et al., 2005). Associated to that, we cannot rule out other CNS diseases that affected our study population based sole on CSF analysis. Moreover, recent studies showed the utility of advanced imaging as CT and MRI in association with CSF analysis in clinical diagnosis of CNS disease in dogs (Bohn et al., 2006; Talarico and Schatzberg, 2010; Lamb et al., 2005).

Limitations of this study should be acknowledge such as small sample size and heterogeneous reasons for performing CSF analysis in neurologically abnormal dogs. Also a majour limit is the fact that the etiology of the CSF changes was confirmed only in two cases.

Prospective and more powerful studies are warranted to adress the CSF analysis on CSF biomarkers for more specific diagnosis.

Acknowledgments: This research did not receive any specific grant from funding agencies in the public, commercial, or not-for-profit sectors.

\section{References}

1. Abate O, Bollo E, Lotti D, Bo S (1998). Cytological, immunocytochemical and biochemical cerebrospinal fluid investigations in selected central nervous system disorders of dogs. J Vet Med B, 45: 73-85.

2. Adamo PF, Adams WM, Steinberg H (2007). Granulomatous Meningoencephalomyelitis in Dogs, Compendium, 2: 678690.

3. Bagley RS, Bohn AA (2003). Interpreting the results of CSF analysis in dogs and cats. Veterinary Medicine, 98:499506.

4. Barber RM, Porter BF, Li Q, May M, Claiborne M K, Allison AB (2012). Broadly reactive polymerase chain reaction for pathogen detection in canine granulomatous meningoencephalomyelitis and necrotizing meningoencephalitis. J Vet Intern Med, Doi: 10.1111/j.1939-1676.2012.00954.x.

5. Bohn AA, Wills TB, West LC, Tucker LR, Bagley RS (2006). Cerebrospinal fluid analysis and magnetic resonance imaging in the diagnosis of neurologic disease in dogs; a retrospective study, Veterinary Clinical Pathology, 35(3): 315-320.

6. Braund KG (1985). Granulomatous meningoencephalomyelitis. JAVMA 18:138-141.

7. Bush WW, Barr CS, Darrin EW, Shofer FS, Vite $\mathrm{CH}$, Steinberg SA (2002) Results of cerebrospinal fluid analysis, neurologic examination findings, and age at the onset of seizures as predictors for results of magnetic resonance imaging of the brain in dogs examined because of seizures: 115 cases (1992-2000), JAVMA, 220(6): 781784.

8. Chrisman C (1992). Cerebrospinal fluid analysis. In M. Moore (Eds.), Diseases of the Spine (pp. 781-809). Philadelphia: WB Saunders.

9. Da Costa R (2012.) Spinal pain. In S. Platt, \& L. Garosi (Eds.), Small Animal Neurological Emergencies (pp. 219228). London, UK: Manson Publishing.

10. Greene CE, Appel MJ (1990). Canine distemper. In C.E. Greene (Eds.), Infectious Diseases of Dogs and Cats (p.232). Philadelphia: WB Saunders.

11. Jamison EM, Lumsden JH (1988). Cerebrospinal fluid analysis in the dog: methodology and interpretation. Semin Vet Med Surg (Small Anim), 3: 122-132.

12. Lamb CR, Croson PJ, Cappello R, Cherubini GB (2005). Magnetic resonance imaging findings in 25 dogs with inflammatory cerebrospinal fluid. Vet Radiol Ultrasound, 46(1): 17-22.

13. O'Neill EJ, Merrett D, Jones B (2005). Granulomatous meningoencephalomyelitis in dogs: a review. Irish Veterinary Journal. Doi:10.1186/2046-0481-58-2-86.

14. Platt SR, Olby NJ (2013). BSAVA Manual of Canine and Feline Neurology. ( $4^{\text {th }}$ ed). Gloucester, BSAVA (Chapter 3).

15. Plummer SB, Wheeler JS, Thrall DE, Kornegay JN (1992). Computed Tomography of Primary Inflammatory Brain Disorders in Dogs and Cats, Veterinary Radiology \& Ultrasound, 33(5): 307-312.

16. Podell M (1996). Seizures in dogs. Vet Clin North Am Small Anim Pract, 26: 779-809.

17. Talarico LR, Schatzberg SJ (2010). Idiopathic granulomatous and necrotising inflammatory disorders of the canine central nervous system: a review and future pespectives, Journal of Small Animal Practice, Doi: 10.1111/j.1748-5827.2009.00823.x.

18. Tipold A (1995). Diagnosis of inflammatory and infectious diseases of the central nervous system in dogs: a retrospective study. J Vet Intern Med. 9(5):304-314. 